\title{
FERTILIZING LIFE OF GOLDEN HAMSTER SPERMATOZOA IN THE FEMALE TRACT
}

\author{
H. MIYAMOTO AND M. C. CHANG \\ Worcester Foundation for Experimental Biology, Inc., \\ Shrewesbury, Massachusetts 01545, U.S.A.
}

(Received 15th March 1972, accepted 2nd May 1972)

\begin{abstract}
Summary. Hamster spermatozoa recovered from the epididymis or the uterus were deposited into the uterine horns at various times before ovulation. It was found that the fertilizing life of hamster spermatozoa in the female tract is about $13 \mathrm{hr}$.
\end{abstract}

The fertilizing life of the spermatozoa of the commoner laboratory animals in the female tract varies according to the species involved. In farm animals, the fertilizing life of spermatozoa in the female tract of the pig (du Mesnil du Buisson \& Dauzier, 1955; Pitkjanen, 1960), sheep (Green, 1947; Dauzier \& Wintenberger, 1952) and cattle (Laing, 1945; Vandeplassche \& Paredis, 1948; Tarosz, 1961) is about 24 to $48 \mathrm{hr}$. The following experiments were performed to ascertain the fertilizing life of golden hamster spermatozoa in the female tract.

Mature golden hamsters, Mesocricetus auratus, were kept in an animal room under conditions of constant temperature $\left(22^{\circ} \mathrm{C}\right)$ and artificial lighting (19.00 to 07.00 hours darkness). Some females were kept under reversed light and dark conditions (03.00 to 15.00 hours darkness) for the recovery of uterine spermatozoa. All females were examined daily for the presence of a postoestrous discharge and then caged according to the day of their oestrous cycle. Only animals exhibiting a regular, 4-day oestrous cycle were used in this experiment.

A suspension of epididymal spermatozoa was prepared by mincing one cauda epididymidis with scissors in $4 \mathrm{ml}$ Hanks' solution. For the preparation of suspensions of ejaculated spermatozoa, females kept under normal or reversed light conditions were killed 10 to 15 min after mating with two males, and the mass of spermatozoa expressed from the uterus were placed in $2 \mathrm{ml} \mathrm{Hanks'}$ solution.

The females to be inseminated were anaesthetized with ether at appropriate times and the uteri were exposed through a mid-ventral incision. About $0.2 \mathrm{ml}$ of the sperm suspension was injected into the lumen of each uterine horn by means of a 23-gauge needle attached to a tuberculin syringe. Groups of females were inseminated at appropriate times before or after the onset of oestrus, which was ascertained by their lordosis in the presence of active males. The time of ovulation was assumed to be about $8 \mathrm{hr}$ after the onset of lordosis (Harvey, Yanagimachi \& Chang, 1961). 
Eggs were recovered about $10 \mathrm{hr}$ after the expected time of ovulation by flushing the oviducts with saline using a 30-gauge needle, and were mounted, fixed, stained and examined for the assessment of fertilization. The eggs that had either a swollen sperm head or male pronucleus in the vitellus with the tail of a fertilizing spermatozoon were recorded as eggs undergoing fertilization.

From Table 1 it can be seen that the highest fertilization rates (92 to $100 \%$ ) occurred when insemination took place within $8 \frac{1}{2} \mathrm{hr}$ of the expected time of ovulation. These rates decreased from $51 \%$ to $66 \%$ if spermatozoa were in the female tract for 10 to $12 \mathrm{hr}$. The rate of fertilization decreased sharply $(20 \%$ to $24 \%$ ) when spermatozoa were present for about $13 \mathrm{hr}$, but a few eggs $\left(2 \%\right.$ to $3 \%$ ) were still fertilized when insemination took place 13 to $15 \frac{1}{2} \mathrm{hr}$ before the expected time of ovulation. None of seventy-seven eggs was fertilized when spermatozoa were deposited in the uterus 16 to $16 \frac{1}{2} \mathrm{hr}$ before the expected time of ovulation.

TABLE 1

FERTILIZING LIFE OF HAMSTER SPERMATOZOA IN THE FEMALE TRACT

\begin{tabular}{|c|c|c|c|c|c|}
\hline \multicolumn{2}{|c|}{ Time of insemination } & \multicolumn{2}{|c|}{ No. of females used } & \multirow[b]{2}{*}{$\begin{array}{l}\text { Total no. } \\
\text { of eggs } \\
\text { examined }\end{array}$} & \multirow{2}{*}{$\begin{array}{c}\text { No. of eggs } \\
\text { undergoing } \\
\text { fertilization } \\
(\%)\end{array}$} \\
\hline $\begin{array}{c}\text { Hours before }(+) \\
\text { or after }(-) \text { the } \\
\text { onset of oestrus }\end{array}$ & $\begin{array}{l}\text { Hours before expected } \\
\text { time of ovulation } \dagger\end{array}$ & Total & $\begin{array}{c}\text { With } \\
\text { fertile } \\
\text { eggs }\end{array}$ & & \\
\hline $\begin{array}{l}-5 \text { to }-5 \cdot 5 \\
-5 \text { to }-5 \cdot 5^{*} \\
-2 \text { to }-2 \cdot 5^{*} \\
-0.5 \text { to }-1^{*} \\
00 \text { to }+0.5 \\
+2 \text { to }+2 \cdot 5^{*} \\
+3 \cdot 5 \text { to }+4 \\
+3 \cdot 5 \text { to }+4^{*} \\
+4 \cdot 5 \text { to }+5 \\
+4 \cdot 5 \text { to }+5^{*} \\
+6 \text { to }+6^{*} \cdot 5 \\
+5 \text { to }+6^{*} \\
+7 \text { to }+7 \cdot 5^{*} \\
+8 \text { to }+8 \cdot 5^{*}\end{array}$ & $\begin{array}{l}2.5 \text { to } 3 \\
2.5 \text { to } 3 \\
5.5 \text { to } 6 \\
7 \text { to } 7 \cdot 5 \\
8 \text { to } 8.5 \\
10 \text { to } 10.5 \\
11.5 \text { to } 12 \\
11.5 \text { to } 12 \\
12.5 \text { to } 13 \\
12.5 \text { to } 13 \\
14 \text { to } 14 \cdot 5 \\
13 \text { to } 14 \\
15 \text { to } 15 \cdot 5 \\
16 \text { to } 16.5\end{array}$ & $\begin{array}{l}4 \\
6 \\
6 \\
6 \\
5 \\
6 \\
6 \\
5 \\
8 \\
6 \\
6 \\
7 \\
6 \\
5\end{array}$ & $\begin{array}{l}4 \\
6 \\
6 \\
6 \\
5 \\
6 \\
6 \\
5 \\
6 \\
5 \\
2 \\
3 \\
2 \\
0\end{array}$ & $\begin{array}{r}57 \\
96 \\
93 \\
100 \\
77 \\
92 \\
92 \\
80 \\
115 \\
97 \\
104 \\
119 \\
95 \\
77\end{array}$ & $\begin{array}{c}57(100) \\
96(100) \\
91(98) \\
100(100) \\
71(92) \\
53(58) \\
61(66) \\
41(51) \\
27(24) \\
19(20) \\
2(2) \\
4(3) \\
2(2) \\
0(0)\end{array}$ \\
\hline
\end{tabular}

* Inseminated with uterine spermatozoa.

t Ovulation usually occurs about $8 \mathrm{hr}$ after the onset of oestrus.

There was no striking difference between spermatozoa recovered from the epididymis and from the uterus 15 min after mating, although a greater proportion of eggs was fertilized by epididymal spermatozoa than by uterine spermatozoa $(61 \%$ versus $43 \%$ ) in animals inseminated 8 to $13 \mathrm{hr}$ before ovulation. This indicates that the secretions from the male accessory glands do not play an important rôle in maintaining the fertilizing life of spermatozoa. Since the fertilizable life of hamster eggs after ovulation is about $12 \mathrm{hr}$ (Yanagimachi \& Chang, 1961), the sharp drop in the fertilization rate following insemination $13 \mathrm{hr}$ before ovulation is not due to the loss of fertilizability of eggs. It may indicate a uniform deterioration of spermatozoa in the female tract. The high fertilization rate obtained by insemination $2 \frac{1}{2}$ to $3 \mathrm{hr}$ before ovulation confirms the reports that hamster spermatozoa reach the site of fertilization within $1 \mathrm{hr}$ of copulation (Yanagimachi \& Chang, 1963) and that 
the capacitation of hamster spermatozoa can be achieved within 2 to $4 \mathrm{hr}$ in the female tract (Strauss, 1956; Chang \& Sheaffer, 1957; Yanagimachi, 1966).

In view of the fact that the fertilizing life of spermatozoa in the female tract is $12 \mathrm{hr}$ in the mouse (McGaughey, Marston \& Chang, 1968), $13 \mathrm{hr}$ in the hamster (present study), $14 \mathrm{hr}$ in the rat (Soderwall \& Blandau, 1941), and $22 \mathrm{hr}$ in the guinea-pig (Soderwall \& Young, 1940), while the fertilizable life of eggs after ovulation is $15 \mathrm{hr}$ in the mouse (Marston \& Chang, 1964), $12 \mathrm{hr}$ in the hamster (Yanagimachi \& Chang, 1961), $12 \mathrm{hr}$ in the rat (Blandau \& Jordan, 1941) and $20 \mathrm{hr}$ in the guinea-pig (Blandau \& Young, 1939), it appears that the fertile lives of rodent spermatozoa and eggs in the female tract are similar in a given species. In other species, the fertilizing life of spermatozoa in the female tract is $30 \mathrm{hr}$ in the rabbit (Hammond \& Asdell, 1926), $126 \mathrm{hr}$ in the ferret (Chang, 1965) and $144 \mathrm{hr}$ in the horse (Day, 1942; Burkhardt, 1949), while the fertilizable life of eggs after ovulation is 6 to $8 \mathrm{hr}$ in the rabbit (Hammond, 1934; Chang, 1952), 30 to $36 \mathrm{hr}$ in the ferret (Hammond \& Walton, 1934; Chang \& Yanagimachi, 1963) and an estimated time of 2 to $20 \mathrm{hr}$ in the mare (Berliner, 1959), i.e. in these species, the fertilizing life of spermatozoa is much longer than the fertilizable life of eggs. Such differences may be evolved according to their different patterns of reproduction.

This work was supported by grants from the U.S. Public Health Service (HD 03472) and the Ford Foundation. Thanks are due to Mrs Virginia Kelleher for assistance.

\section{REFERENCES}

Berliner, V. R. (1959) The estrous cycle of the mare. In: Reproduction in Domestic Animals, Vol. I, Chap. 8. Ed. H. H. Cole and P. T. Cupps. Academic Press, New York.

Blandau, R. J. \& Jordan, E. S. (1941) The effect of delayed fertilization on the development of the rat ovum. Am. F. Anat. 68, 275.

Blandau, R. J. \& Young, W. C. (1939) The effects of delayed fertilization on the development of the guinea pig ovum. Am. J. Anat. 64, 303.

Burkhard, J. (1949) Sperm survival in the genital tract of the mare. F. agric. Sci., Camb. 39, 201.

Chang, M. C. (1952) Fertilizability of rabbit ova and the effects of temperature in vitro on their subsequent fertilization and activation in vivo. F. exp. Zool. 121, 351.

Chang, M. C. (1965) Fertilizing life of ferret sperm in the female tract. F. exp. Zool. 158, 87.

Chang, M. C. \& ShEaffer, D. (1957) Number of spermatozoa ejaculated at copulation, transported into the female tract, and present in the male tract of the golden hamster. F. Hered. 48, 107.

Chang, M. C. \& Yanagimachi, R. (1963) Fertilization of ferret ova by deposition of epididymal sperm into the ovarian capsule with special reference to the fertilizable life of ova and the capacitation of sperm. F. exp. Zool. 154, 175.

Dauzier, L. \& Wintenberger, S. (1952) La vitesse de remontée des spermatozoïdes dans le tractus génital de la brebis. Annls Inst. natn. Rech. agron. no. 1, 13.

DAy, F. T. (1942) Survival of spermatozoa in the genital tract of the mare. F. agric. Sci., Camb. 32, 108. du Mesnil du Buisson, F. \& Dauzier, L. (1955) Distribution et résorption du sperme dans le tractus génital de la truie des spermatozoïdes. Annls Endocr. 16, 413.

Green, W. W. (1947) Duration of sperm fertility in the ewe. Am. F. vet. Res. 8, 299.

Hammond, J. (1934) The fertilization of rabbit ova in relation to time: a method of controlling litter size, the duration of pregnancy and weight of young at birth. F. exp. Biol. 11, 140.

Hammond, J. \& AsDell, S. A. (1926) The vitality of spermatozoa in the male and female reproductive tract. F. exp. Biol. 4, 155.

Hammond, J. \& Walton, A. (1934) Notes on ovulation and fertilization in the ferret. F. exp. Biol. 11, 307.

Harvey, E. B., Yanagimachi, R. \& Chang, M. C. (1961) Onset of estrus and ovulation in the golden hamster. J. exp. Zool. 146, 231. 
LAING, J. A. (1945) Observations on the survival time of the spermatozoa in the genital tract of the cow and its relation to fertility. F. agric. Sci., Camb. 35, 72.

Marston, J. H. \& Chang, M. C. (1964) The fertilizable life of ova and their morphology following delayed insemination in mature and immature mice. F. exp. Zool. 155, 237.

MaGaughey, R. W., Marston, J. H. \& Chang, M. C. (1968) Fertilizing life of mouse spermatozoa in the female tract. F. Reprod. Fert. 16, 147.

PrtKJAnen, I. G. (1960) The fate of spermatozoa in the uterus of the sow. Zh. obshch. Biol. 21, 28.

Soderwald, A. L. \& Blandau, R. J. (1941) The duration of the fertilizing capacity of spermatozoa in genital tract of the rat. $\mathcal{F}$. exp. Zool. 88, 55.

Soderwald, A. L. \& Young, W. G. (1940) The effect of aging in the female genital tract of the fertilizing capacity of guinea pig spermatozoa. Anat. Rec. 78, 19.

Strauss, F. (1956) The time and place of fertilization of the golden hamster egg. F. Embryol. exp. Morph. 4, 42.

TARosz, S. (1961) Obtaining fertilized and unfertilized ova following spontaneous and induced ovulation in cows. Zesz. nauk. wyzsz. Szk. roln. Krakow, (Zootech. Z.), 2, 105. See Anim. Breed. Abstr. 30, $187(1962)$.

Vandeplassche, M. \& Paredis, F. (1948) Preservation of the fertilizing capacity of bull semen in the genital tract of the cow. Nature, Lond. 162, 813.

YANAGIMACHI, R. (1966) Time and process of sperm penetration into hamster ova in vitro and in vivo. 7. Reprod. Fert. 11, 359.

Yanagmachi, R. \& Chang, M. G. (1961) Fertilizable life of golden hamster ova and their morphological changes at the time of losing fertilizability. $\mathcal{F}$. exp. Zool. 148, 185.

Yanagimachi, R. \& Chang, M. C. (1963) Sperm ascent through the oviduct of the hamster and rabbit in relation to the time of ovulation. $\mathcal{F}$. Reprod. Fert. 6, 413. 